Front Biosci. ; 12: 3468-3474.

\title{
Targeting the tumor microenvironment
}

\author{
Paraic A. Kenny, Genee Y. Lee, and Mina J. Bissell \\ Life Sciences Division, Lawrence Berkeley National Laboratory, University of California, Berkeley, \\ CA 94720
}

\begin{abstract}
Despite some notable successes cancer remains, for the most part, a seemingly intractable problem. There is, however, a growing appreciation that targeting the tumor epithelium in isolation is not sufficient as there is an intricate mutually sustaining synergy between the tumor epithelial cells and their surrounding stroma. As the details of this dialogue emerge, new therapeutic targets have been proposed. The FDA has already approved drugs targeting microenvironmental components such as VEGF and aromatase and many more agents are in the pipeline. In this article, we describe some of the "druggable" targets and processes within the tumor microenvironment and review the approaches being taken to disrupt these interactions.
\end{abstract}

\section{Keywords}

Tumor Microenvironment; Cancer; Cancer Therapy; Stromal-Epithelial Interaction; Review

\section{Introduction}

Cancer was long viewed as a cell-autonomous process, in which successive acquisition of mutations in oncogenes and tumor suppressor genes resulted in progressively enhanced proliferation and resistance to cell death. This is now widely viewed as an oversimplification and the recognition that additional cell types and the soluble factors they produce make a vital contribution to epithelial tumorigenesis.

Carcinomas are complex organs (1) consisting of tumor epithelial cells, in a microenvironment rich in multiple non-malignant, albeit altered, cell types - fibroblasts, endothelial cells and leukocytes - all of which interact, either physically or via the secretion of paracrine signaling molecules. In this respect, the tumor organ is no different from all of the other organs, the form and function of which are the product of an exquisite dialogue between the epithelial and stromal cells, and an understanding of the processes driving its biogenesis should prove to be the making of its undoing.

While this paradigm shift has caused a fundamental reevaluation of how cancer biologists think about tumorigenesis, it is really "old news" for developmental biologists who, for almost a century, have realized that cues from adjacent cell types can induce important changes in cell fate during development. Here, the intricate cross-talk of soluble factors between epithelial and mesenchymal cells plays a vital role in tissue morphogenesis and function. This field was first illuminated by the work of Spemann and Mangold in salamanders (2), which showed that ectopically engrafted tissue could modulate the differentiation of adjacent structures. Later, co-culture experiments were used to define some of the reciprocal interactions between

Send correspondence to: Dr Paraic A. Kenny or Dr. Mina J. Bissell, Life Sciences Division, Lawrence Berkeley National Laboratory, Berkeley, CA 94720 USA, Tel: 510-486-4365, Fax 510-486-5586, pakenny@lbl.gov or mjbissell@1bl.gov. 
epithelium and stroma which are necessary for the induction of the differentiated state $(3,4)$, and these principles have been shown to hold true in many organs, including the mammary gland, kidney and prostate (for reviews see 5,6,7).

A broad appreciation of the importance of heterotypic cell-cell interactions in tumor induction and progression lagged considerably behind, despite the intermittent publication of compelling papers on this subject. The demonstration by Judah Folkman (8) that tumors had the power to stimulate the growth of new blood vessels provided further convincing evidence that tumorigenesis could not proceed without active cooperation from non-malignant cells. DeCosse and coworkers showed that a mammary tumor could be induced to differentiate by co-culture with normal mammary stroma (9). Leland Chung and his colleagues showed that co-injection of either normal or transformed fibroblasts could enhance the tumorigenicity of several different human cancer cell lines in xenograft experiments (10). Similarly, Cunha and co-workers showed that fibroblasts from reactive stromal regions of tumors had the capacity to transform otherwise non-malignant prostate epithelial cells $(7,11)$. More recently, evidence is emerging that mutations in proto-oncogenes and tumor suppressor genes (12) as well as distinctive epigenetic changes (13) are not always restricted to the tumor epithelium and that clones of altered stromal cells been observed further supports the contention that tumor-stromal co-evolution can be an important driver of tumorigenesis.

It is also clear that only a proportion of familial cancers are explained by the inheritance of strongly predisposing mutant alleles, such as BRCA1, BRCA2 and APC. A significant fraction of the remaining familial component is likely to arise from the contribution of lower penetrance alleles which, while having weak effects alone, may lower the threshold at which tumorigenesis is likely to occur. Interestingly, SNPs altering the expression level or activity of a number of microenvironmental proteins have been reported to predispose to cancer (reviewed in 14).

Following up from Beatrice Mintz's demonstration that transformed embryonal carcinoma cells injected into blastocysts could contributed to tumor-free tissues in adult mice (15), work in the 1980 's from our laboratory showed that expression of the viral Src oncogene did not result in cellular transformation in the developing chick embryo, yet dissociated cells were demonstrably transformed in culture. These studies led to the realization that even expression of a potent oncogene was not sufficient for transformation and that additional factors, such as disruption of tissue architecture by wounding, may be necessary $(16,17)$. These studies were consistent with the ideas of Dvorak on the similarities between tumors and wounds (18) and also the growing appreciation of the relationships between inflammation and tumorigenesis (see below). In the chick model, TGF-beta was implicated as a key mediator in this process (19) a finding which conflicted with the then dominant theory of TGF-beta as a proliferation suppressor; subsequent studies established that disruption of the microenvironment by excessive production of matrix metalloproteinases (MMPs) can lead to genomic instability, epithelial-to-mesenchymal transition and malignant transformation of mammalian cells in vitro and in vivo (20-22).

Collectively, these studies established that heterotypic cell-cell interactions were critical to tumor induction and progression, but the identity of many of the molecular mediators of this communication remained to be determined. In the past few years, considerable progress has been made toward identifying some of the key signaling processes which underlie epithelialstromal interactions. This newfound understanding has opened the way to the design of rational therapies which target the microenvironment of the tumor, as a means of destroying the tumor itself. 


\section{Heterotypic Cell Signaling Mediators}

The extent to which soluble factors which are secreted by one cell type and act by binding receptors on other cell types influence the malignant process is now widely appreciated. This has provided a profusion of therapeutic leads, some of which are already approved drugs and many more of which are in the pipeline. One example of a signaling molecule targeted in this way is tumor necrosis factor alpha (TNF-alpha which, although originally believed to have predominantly anti-tumor activity, has more recently been shown to exert many protumorigenic functions (23). One approach has led to the generation of an anti-TNF-alpha monoclonal antibody, Infliximab, which is approved in the US for the treatment of Crohn disease and ulcerative colitis, both of which predispose to colorectal cancer. An alternative strategy, to build a decoy receptor which will sequester soluble TNF-alpha is marketed as Etanercept and is approved for the treatment of rheumatoid arthritis. Monoclonal antibodies against TNF-alpha have shown efficacy in a series of preclinical models (23) and both of these drugs are in clinical trials to test efficacy in cancer. This paradigm of using decoy receptors and blocking antibodies is a recurrent theme in microenvironment-directed therapies.

Cells of the immune system have long been observed in association with tumors (24). This was thought to reflect the body's response to the tumor organ, but several studies have now shown that such lymphocytic infiltrates actually correlate with poor prognosis (25). Tumor cells secrete a series of chemokines which actively promote macrophage recruitment $(26,27)$. Pollard and co-workers have delineated an important feedback loop by which tumors recruit cells of the immune system, which then provide the tumors with mitogenic stimuli. CSF1, produced by tumor cells is a potent chemoattractant for macrophages. Macrophages are rich in growth factors, such as EGF, and proteases, which can promote tumor cell proliferation, angiogenesis and matrix remodeling, all of which can facilitate progression (28). Treatments which have shown promise against tumor-associated macrophages include Trabectedin (29) and a blocking antibody against CSF1 which has shown significant efficacy in a breast cancer xenograft model (30).

Instead of targeting macrophages, another exciting approach has been the proposal to use macrophages (or, more likely their monocyte precursors) as vehicles for gene therapy (27). This builds on the approach pioneered by Rosenberg of gene transfer into tumor infiltrating lymphocytes (31). Because they accumulate preferentially in hypoxic areas of tumors, macrophages may prove an effective means of drug delivery to regions of the tumor which are difficult to target by other means and which are believed to contain cells which are more resistant to chemotherapies. As proof of principle, it was shown that macrophages transduced with CYP2B6 could infiltrate tumor spheroids grown in vitro and activate cyclophosphamide, resulting in death of adjacent tumor cells (32). Similarly, Dubinett, Sharma and colleagues demonstrated that introducing dendritic cells transduced with CCL21 into the tumor microenvironment in a transgenic mouse model of broncheoalveolar cell carcinoma results in the recruitment of many endogenous dendritic cells, T-lymphocytes and natural killer cells, which significantly extended the survival of the mice (33). Vinel and co-workers have shown efficacy of fibroblasts transduced with IL-12 in mouse models of pancreatic and hepatocellular carcinoma $(34,35)$.

Transforming growth factor beta (TGF-beta) has complex autocrine and paracrine roles in tumor progression. This factor is a potent inhibitor of epithelial cell growth, but sensitivity to these effects of TGF-beta is frequently lost during tumor progression and, in later stages, TGFbeta signaling has pro-oncogenic functions which is reflected by the poor prognosis of tumors of many tissues which overexpress TGF-beta (36). Compelling evidence for a role of this pathway in stromal-epithelial crosstalk emerged from the work of Moses and colleagues, who showed that deletion of the TGF-beta type II receptor in stromal fibroblasts resulted in the 
transformation of adjacent epithelia in the prostate and forestomach (37). Fibroblasts from these animals have upregulated expression of growth factors and increased the proliferation of mammary cancer cells when co-injected beneath the kidney capsule (38). Existing strategies to target this pathway include small molecule inhibitors of the receptors, and antibodies and decoy receptors which prevent ligand-receptor interactions (39).

\section{Nonsteroidal Anti-Inflammatory Drugs (NSAIDs)}

As many as 1 in 6 epithelial cancers are believed to arise at sites of inflammation $(40,41)$, suggesting that the disruption of tissue architecture, the influx of immune cells and the tissue repair processes might allow pre-existing neoplastic cells to escape the constraints imposed on them by their microenvironment. Large observational studies of hundreds of thousands of individuals have associated frequent aspirin use with a significantly reduced incidence of colorectal cancer $(42,43)$, and evidence is also increasing that NSAID use may help in the chemoprevention of cancers of the breast, ovary, prostate and lung (44, and references therein). NSAIDs suppress the activity of the cyclooxygenases, COX1 and COX2, the latter being the primary inducible form which produces prostaglandins in inflammation and in tumors. Prostaglandins activate a diverse array of signaling pathways with pro-tumorigenic roles (45).

\section{Angiogenesis Inhibitors}

The recruitment of a vasculature to supply blood and oxygen is an essential transition which must occur if a tumor is to grow larger than a couple of $\mathrm{mm} 3$, which is the diffusion limit for oxygen in vivo. Angiogenesis is regulated by a delicate balance between a series of pro- and anti-angiogenic factors. Because the vasculature is genomically stable, it was hypothesized that targeting this key aspect of the malignant phenotype might prove effective therapeutically while having less risk of developing somatically acquired resistance. Several angiogenesis inhibitors are in development and some have already been approved. Bevacizumab (AvastinTM), a humanized monoclonal anti-VEGF antibody has been approved in combination with 5-Fluorouracil for the treatment of metastatic colorectal cancer (46), and following this validation many other anti-VEGF agents are at various stages of development (47). The arsenal of anti-angiogenic drugs has been further expanded following the realization that the receptor tyrosine kinases which are activated by these ligands are also inhibited by existing drugs. BAY 43-9006, a Raf inhibitor, also potently inhibits VEGFR2 and VEGFR3 (48). Gleevec, which is approved for inhibition of cKIT in gastrointestinal stromal tumors and BCR-ABL in chronic myelogenous leukemia, is also a potent inhibitor of the PDGF Receptor (49). Targeting PDGFR on pericytes, with consequent disruption of the tumor vasculature, may prove an unforeseen bonus of using Gleevec, and may indeed contribute to its effectiveness in vivo. In some cases, it seems, the "off-target" effects of a drug might be beneficial!

The new interest in angiogenesis has led also to the rehabilitation of an older drug, Thalidomide, which was removed from sale in 1962 when it was realized it caused birth defects in children. Thalidomide is a potent inhibitor of angiogenesis (50), and clinical efficacy has been demonstrated in multiple myeloma (51). In 2005 it was approved in Australia for the treatment of this disease, and the US FDA followed suit in 2006.

As our understanding of the role of the extracellular matrix in the maintenance of tissue homeostasis has improved, it has been realized that many extracellular matrix proteins possess cryptic fragments which, when released by cleavage, can exert potent biological effects. Examples of such fragments include Canstatin and Tumstatin (from Collagen IV), endostatin (from Collagen XVIII), Angiostatin (from plasminogen) and Restin (from Collagen XV), all of which exert antiangiogenic effects (52). Intriguingly, Collagen XVIII, from which Endostatin is derived, is located on Chromosome 21, the chromosome of which three copies 
are found in individuals with Down syndrome. When controlled for age, individuals with Down syndrome develop epithelial cancers at one tenth of the rate of unaffected individuals (53). Transgenic mice engineered to overexpress endostatin experience a significant reduction in the rate of tumor growth (54). In clinical trials $(55,56)$, recombinant human endostatin failed to live up to the dramatic promise it showed in earlier pre-clinical studies (57), however a new more soluble variant called Endostar (58) was approved in China in 2005 (59) and we eagerly await the further evaluation of this peptide in additional studies.

\section{Aromatase Inhibitors}

For ER-alpha positive breast cancers, estrogen provides a crucial mitogenic cue and estrogen receptor antagonists, such as tamoxifen, have had a very significant impact in the clinic. Estradiol is synthesized in the ovaries and at extragonadal sites, with extragonadal synthesis being dominant after the menopause. In postmenopausal women with estrogen-dependent breast cancer, estrogen produced locally within the breast stromal fibroblasts and adipocytes is the primary source of this factor $(60,61)$. Aromatase in these cells is a key enzyme in estradiol biosynthesis and so represents an excellent target for microenvironment targeted therapy. This is a clear example of a crucial growth factor being synthesized in the breast tumor microenvironment by a "druggable" target. The third-generation aromatase inhibitors anastrazole, letrozole and exemesthane - can inhibit whole body aromatization by up to $98 \%$. The aromatase inhibitors have been shown to be even more effective than tamoxifen at preventing breast cancer recurrence in post-menopausal women (62). This remains, to our knowledge, the most successful example yet of a therapy targeted at a component in the microenvironment resulting in strong efficacy against tumors in a clinical setting.

\section{Bisphosphonates}

More than a century ago, Paget observed that tumors of different tissues exhibited an apparent preference in the distant sites at which metastases were established, likening tumor cells to seeds which could only flourish if they fall on a congenial soil (63). Metastasis to bone is a frequent event in advanced cancer, leading to pain, a loss of bone mineral density and an increased susceptibility to fractures. The microenvironment of the bone is particularly hospitable to the cells of prostate, breast and renal tumors and multiple myeloma, all of which can adapt very well to this niche. Bisphosphonates, such as Zoledronic Acid, Ibandronate, Pamidronate and Clodronate, achieve high local concentrations by binding to bone hydroxyapatite, leading to loss of osteoclasts and, consequently, an attenuation of bone resorption. These pyrophosphate analogs are effective inhibitors of the mevalonate pathway resulting in a defect in the prenylation of signaling proteins, leading to osteoclast apoptosis. Inhibition of the same pathway by Zoledronic Acid in tumor cells might also elicit direct antitumor effects (64).

Zoledronic acid has shown considerable promise in the treatment of tumors metastasizing to bone (reviewed in 65). For example, if treatment is started when bone loss due to multiple myeloma is first detected, this significantly reduces the incidence and delays the time of onset of skeletal complications. Preliminary data from a number of trials using bisphosphonates less potent than Zoledronic Acid (reviewed in 66) suggest that this treatment may also prevent breast cancer metastasis to bone. A number of trials are now underway to test the more potent compound in the adjuvant setting.

\section{Conclusions}

We are now coming to the appreciation that the complexities of cancer will rarely be solved by single agents and that rational combinations of targeted therapies chosen on the basis of the particular lesions in individual tumors will be necessary. The scientific arguments for this are 
clear and the moral arguments are compelling. It is frustrating, however, that the financial interests of pharmaceutical companies are often at odds with the interests of patients, and that the legal and regulatory barriers to testing combinations of patented drugs in large trials are depressingly prohibitive (67). Nevertheless, we remain greatly encouraged that so many colleagues now appreciate the importance of targeting the tumor microenvironment and, as our collective understanding of the complexities of tumor ecology deepens, we hope that patients will soon benefit from drug combinations targeting the whole tumor organ and not just its epithelial component.

\section{Acknowledgments}

The work in the authors' laboratory is supported by grants from the U.S. Department of Energy (DE-AC03-76SF00098 and a Distinguished Fellow Award), the NIH (CA64786; and CA57621 to Zena Werb and MJB), and by an Innovator award from the U.S. Department of Defense Breast Cancer Research Program.

\section{References}

1. Bissell MJ, Radisky D. Putting tumours in context. Nat Rev Cancer 2001;1:46-54. [PubMed: 11900251]

2. Spemann, H.; Mangold, H. Induction of embryonic primordia by implantation of organizers from a different species. In: Willier, BH.; Oppenheimer, JM., editors. Foundations of Experimental Embryology. Hafner; New York: 1924.

3. Grobstein C. Cytodifferentiation and Its Controls. Science 1964;143:643-50. [PubMed: 14081236]

4. Sakakura T, Nishizuka Y, Dawe CJ. Mesenchyme-dependent morphogenesis and epithelium-specific cytodifferentiation in mouse mammary gland. Science 1976;194:1439-41. [PubMed: 827022]

5. Wiseman BS, Werb Z. Stromal effects on mammary gland development and breast cancer. Science 2002;296:1046-9. [PubMed: 12004111]

6. Karihaloo A, Nickel C, Cantley LG. Signals which build a tubule. Nephron Exp Nephrol 2005;100:e405. [PubMed: 15731568]

7. Cunha GR, Ricke W, Thomson A, Marker PC, Risbridger G, Hayward SW, Wang YZ, Donjacour AA, Kurita T. Hormonal, cellular, and molecular regulation of normal and neoplastic prostatic development. J Steroid Biochem Mol Biol 2004;92:221-36. [PubMed: 15663986]

8. Folkman J. Tumor angiogenesis: therapeutic implications. N Engl J Med 1971;285:1182-6. [PubMed: 4938153]

9. DeCosse JJ, Gossens CL, Kuzma JF, Unsworth BR. Breast cancer: induction of differentiation by embryonic tissue. Science 1973;181:1057-8. [PubMed: 4269415]

10. Camps JL, Chang SM, Hsu TC, Freeman MR, Hong SJ, Zhau HE, von Eschenbach AC, Chung LW. Fibroblast-mediated acceleration of human epithelial tumor growth in vivo. Proc Natl Acad Sci U S A 1990;87:75-9. [PubMed: 2296606]

11. Olumi AF, Grossfeld GD, Hayward SW, Carroll PR, Tlsty TD, Cunha GR. Carcinoma-associated fibroblasts direct tumor progression of initiated human prostatic epithelium. Cancer Res 1999;59:5002-11. [PubMed: 10519415]

12. Moinfar F, Man YG, Arnould L, Bratthauer GL, Ratschek M, Tavassoli FA. Concurrent and independent genetic alterations in the stromal and epithelial cells of mammary carcinoma: implications for tumorigenesis. Cancer Res 2000;60:2562-6. [PubMed: 10811140]

13. Hu M, Yao J, Cai L, Bachman KE, van den Brule F, Velculescu V, Polyak K. Distinct epigenetic changes in the stromal cells of breast cancers. Nat Genet 2005;37:899-905. [PubMed: 16007089]

14. Bissell MJ, Kenny PA, Radisky DC. Microenvironmental regulators of tissue structure and function also regulate tumor induction and progression: the role of extracellular matrix and its degrading enzymes. Cold Spring Harb Symp Quant Biol 2005;70:343-56. [PubMed: 16869771]

15. Mintz B, Illmensee K. Normal genetically mosaic mice produced from malignant teratocarcinoma cells. Proc Natl Acad Sci U S A 1975;72:3585-9. [PubMed: 1059147]

16. Dolberg DS, Bissell MJ. Inability of Rous sarcoma virus to cause sarcomas in the avian embryo. Nature 1984;309:552-6. [PubMed: 6203040] 
17. Dolberg DS, Hollingsworth R, Hertle M, Bissell MJ. Wounding and its role in RSV-mediated tumor formation. Science 1985;230:676-8. [PubMed: 2996144]

18. Dvorak HF. Tumors: wounds that do not heal. Similarities between tumor stroma generation and wound healing. N Engl J Med 1986;315:1650-9. [PubMed: 3537791]

19. Sieweke MH, Bissell MJ. The tumor-promoting effect of wounding: a possible role for TGF-betainduced stromal alterations. Crit Rev Oncog 1994;5:297-311. [PubMed: 7849089]

20. Lochter A, Galosy S, Muschler J, Freedman N, Werb Z, Bissell MJ. Matrix metalloproteinase stromelysin-1 triggers a cascade of molecular alterations that leads to stable epithelial-tomesenchymal conversion and a premalignant phenotype in mammary epithelial cells. J Cell Biol 1997;139:1861-72. [PubMed: 9412478]

21. Radisky DC, Levy DD, Littlepage LE, Liu H, Nelson CM, Fata JE, Leake D, Godden EL, Albertson DG, Nieto MA, Werb Z, Bissell MJ. Rac1b and reactive oxygen species mediate MMP-3-induced EMT and genomic instability. Nature 2005;436:123-7. [PubMed: 16001073]

22. Sternlicht MD, Lochter A, Sympson CJ, Huey B, Rougier JP, Gray JW, Pinkel D, Bissell MJ, Werb $\mathrm{Z}$. The stromal proteinase MMP3/stromelysin-1 promotes mammary carcinogenesis. Cell 1999;98:137-46. [PubMed: 10428026]

23. Szlosarek P, Charles KA, Balkwill FR. Tumour necrosis factor-alpha as a tumour promoter. Eur J Cancer 2006;42:745-50. [PubMed: 16517151]

24. Virchow, R. Die Krankenhaften Geschwulste. Verlag von August Hirschwald; Berlin: 1863. Aetologie der neoplastichen Geschwulste/Pathogenie der neoplastischen Geschwulste.

25. Bingle L, Brown NJ, Lewis CE. The role of tumour-associated macrophages in tumour progression: implications for new anticancer therapies. J Pathol 2002;196:254-65. [PubMed: 11857487]

26. Mantovani A, Allavena P, Sozzani S, Vecchi A, Locati M, Sica A. Chemokines in the recruitment and shaping of the leukocyte infiltrate of tumors. Semin Cancer Biol 2004;14:155-60. [PubMed: 15246050]

27. Murdoch C, Giannoudis A, Lewis CE. Mechanisms regulating the recruitment of macrophages into hypoxic areas of tumors and other ischemic tissues. Blood 2004;104:2224-34. [PubMed: 15231578]

28. Condeelis J, Pollard JW. Macrophages: obligate partners for tumor cell migration, invasion, and metastasis. Cell 2006;124:263-6. [PubMed: 16439202]

29. Allavena P, Signorelli M, Chieppa M, Erba E, Bianchi G, Marchesi F, Olimpio CO, Bonardi C, Garbi A, Lissoni A, de Braud F, Jimeno J, D'Incalci M. Anti-inflammatory properties of the novel antitumor agent yondelis (trabectedin): inhibition of macrophage differentiation and cytokine production. Cancer Res 2005;65:2964-71. [PubMed: 15805300]

30. Paulus P, Stanley ER, Schafer R, Abraham D, Aharinejad S. Colony-stimulating factor-1 antibody reverses chemoresistance in human MCF-7 breast cancer xenografts. Cancer Res 2006;66:4349-56. [PubMed: 16618760]

31. Rosenberg SA, Aebersold P, Cornetta K, Kasid A, Morgan RA, Moen R, Karson EM, Lotze MT, Yang JC, Topalian SL, et al. Gene transfer into humans--immunotherapy of patients with advanced melanoma, using tumor-infiltrating lymphocytes modified by retroviral gene transduction. $\mathrm{N} \mathrm{Engl} \mathrm{J}$ Med 1990;323:570-8. [PubMed: 2381442]

32. Griffiths L, Binley K, Iqball S, Kan O, Maxwell P, Ratcliffe P, Lewis C, Harris A, Kingsman S, Naylor S. The macrophage - a novel system to deliver gene therapy to pathological hypoxia. Gene Ther 2000;7:255-62. [PubMed: 10694803]

33. Yang SC, Batra RK, Hillinger S, Reckamp KL, Strieter RM, Dubinett SM, Sharma S. Intrapulmonary administration of CCL21 gene-modified dendritic cells reduces tumor burden in spontaneous murine bronchoalveolar cell carcinoma. Cancer Res 2006;66:3205-13. [PubMed: 16540672]

34. Peron JM, Couderc B, Rochaix P, Douin-Echinard V, Asnacios A, Souque A, Voigt JJ, Buscail L, Vinel JP, Favre G. Treatment of murine hepatocellular carcinoma using genetically modified cells to express interleukin-12. J Gastroenterol Hepatol 2004;19:388-96. [PubMed: 15012775]

35. Peron JM, Bureau C, Gourdy P, Lulka H, Souque A, Calippe B, Selves J, Al Saati T, Bernad J, Cordelier P, Couderc B, Pradayrol L, Pipy B, Buscail L, Vinel JP. Treatment of pancreatic peritoneal carcinomatosis with fibroblasts genetically modified to express IL-12: a role for peritoneal innate immunity. Gut. 2006 
36. Levy L, Hill CS. Alterations in components of the TGF-beta superfamily signaling pathways in human cancer. Cytokine Growth Factor Rev 2006;17:41-58. [PubMed: 16310402]

37. Bhowmick NA, Chytil A, Plieth D, Gorska AE, Dumont N, Shappell S, Washington MK, Neilson EG, Moses HL. TGF-beta signaling in fibroblasts modulates the oncogenic potential of adjacent epithelia. Science 2004;303:848-51. [PubMed: 14764882]

38. Cheng N, Bhowmick NA, Chytil A, Gorksa AE, Brown KA, Muraoka R, Arteaga CL, Neilson EG, Hayward SW, Moses HL. Loss of TGF-beta type II receptor in fibroblasts promotes mammary carcinoma growth and invasion through upregulation of TGF-alpha-, MSP- and HGF-mediated signaling networks. Oncogene 2005;24:5053-68. [PubMed: 15856015]

39. Arteaga CL. Inhibition of TGFbeta signaling in cancer therapy. Curr Opin Genet Dev 2006;16:307. [PubMed: 16377175]

40. Balkwill F, Charles KA, Mantovani A. Smoldering and polarized inflammation in the initiation and promotion of malignant disease. Cancer Cell 2005;7:211-7. [PubMed: 15766659]

41. Karin M, Greten FR. NF-kappaB: linking inflammation and immunity to cancer development and progression. Nat Rev Immunol 2005;5:749-59. [PubMed: 16175180]

42. Giovannucci E, Rimm EB, Stampfer MJ, Colditz GA, Ascherio A, Willett WC. Aspirin use and the risk for colorectal cancer and adenoma in male health professionals. Ann Intern Med 1994;121:2416. [PubMed: 8037405]

43. Thun MJ, Namboodiri MM, Heath CW Jr. Aspirin use and reduced risk of fatal colon cancer. N Engl J Med 1991;325:1593-6. [PubMed: 1669840]

44. Ulrich CM, Bigler J, Potter JD. Non-steroidal anti-inflammatory drugs for cancer prevention: promise, perils and pharmacogenetics. Nat Rev Cancer 2006;6:130-40. [PubMed: 16491072]

45. Wang D, Dubois RN. Prostaglandins and cancer. Gut 2006;55:115-22. [PubMed: 16118353]

46. Hurwitz H, Fehrenbacher L, Novotny W, Cartwright T, Hainsworth J, Heim W, Berlin J, Baron A, Griffing S, Holmgren E, Ferrara N, Fyfe G, Rogers B, Ross R, Kabbinavar F. Bevacizumab plus irinotecan, fluorouracil, and leucovorin for metastatic colorectal cancer. N Engl J Med 2004;350:2335-42. [PubMed: 15175435]

47. Ferrara N, Hillan KJ, Gerber HP, Novotny W. Discovery and development of bevacizumab, an antiVEGF antibody for treating cancer. Nat Rev Drug Discov 2004;3:391-400. [PubMed: 15136787]

48. Wilhelm SM, Carter C, Tang L, Wilkie D, McNabola A, Rong H, Chen C, Zhang X, Vincent P, McHugh M, Cao Y, Shujath J, Gawlak S, Eveleigh D, Rowley B, Liu L, Adnane L, Lynch M, Auclair D, Taylor I, Gedrich R, Voznesensky A, Riedl B, Post LE, Bollag G, Trail PA. BAY 43-9006 exhibits broad spectrum oral antitumor activity and targets the RAF/MEK/ERK pathway and receptor tyrosine kinases involved in tumor progression and angiogenesis. Cancer Res 2004;64:7099-109. [PubMed: 15466206]

49. Buchdunger E, Cioffi CL, Law N, Stover D, Ohno-Jones S, Druker BJ, Lydon NB. Abl proteintyrosine kinase inhibitor STI571 inhibits in vitro signal transduction mediated by c-kit and plateletderived growth factor receptors. J Pharmacol Exp Ther 2000;295:139-45. [PubMed: 10991971]

50. D'Amato RJ, Loughnan MS, Flynn E, Folkman J. Thalidomide is an inhibitor of angiogenesis. Proc Natl Acad Sci U S A 1994;91:4082-5. [PubMed: 7513432]

51. Barlogie B, Tricot G, Anaissie E, Shaughnessy J, Rasmussen E, van Rhee F, Fassas A, Zangari M, Hollmig K, Pineda-Roman M, Lee C, Talamo G, Thertulien R, Kiwan E, Krishna S, Fox M, Crowley J. Thalidomide and hematopoietic-cell transplantation for multiple myeloma. N Engl J Med 2006;354:1021-30. [PubMed: 16525139]

52. Folkman J. Antiangiogenesis in cancer therapy--endostatin and its mechanisms of action. Exp Cell Res 2006;312:594-607. [PubMed: 16376330]

53. Yang Q, Rasmussen SA, Friedman JM. Mortality associated with Down's syndrome in the USA from 1983 to 1997: a population-based study. Lancet 2002;359:1019-25. [PubMed: 11937181]

54. Sund M, Hamano Y, Sugimoto H, Sudhakar A, Soubasakos M, Yerramalla U, Benjamin LE, Lawler J, Kieran M, Shah A, Kalluri R. Function of endogenous inhibitors of angiogenesis as endotheliumspecific tumor suppressors. Proc Natl Acad Sci U S A 2005;102:2934-9. [PubMed: 15710885]

55. Herbst RS, Hess KR, Tran HT, Tseng JE, Mullani NA, Charnsangavej C, Madden T, Davis DW, McConkey DJ, O'Reilly MS, Ellis LM, Pluda J, Hong WK, Abbruzzese JL. Phase I study of 
recombinant human endostatin in patients with advanced solid tumors. J Clin Oncol 2002;20:3792803. [PubMed: 12228199]

56. Thomas JP, Arzoomanian RZ, Alberti D, Marnocha R, Lee F, Friedl A, Tutsch K, Dresen A, Geiger P, Pluda J, Fogler W, Schiller JH, Wilding G. Phase I pharmacokinetic and pharmacodynamic study of recombinant human endostatin in patients with advanced solid tumors. J Clin Oncol 2003;21:22331. [PubMed: 12525513]

57. Boehm T, Folkman J, Browder T, O'Reilly MS. Antiangiogenic therapy of experimental cancer does not induce acquired drug resistance. Nature 1997;390:404-7. [PubMed: 9389480]

58. Song HF, Liu XW, Zhang HN, Zhu BZ, Yuan SJ, Liu SY, Tang ZM. Pharmacokinetics of His-tag recombinant human endostatin in Rhesus monkeys. Acta Pharmacol Sin 2005;26:124-8. [PubMed: 15659125]

59. Sun Y, Wang J, Liu Y, Song X, Zhang Y, Li K, Zhu Y, Zhou Q, You L, Y C. Results of Phase III trial of EndostarTM (rh-endostatin, YH-16) in advanced non-small cell lung cancer (NSCLC) patients. J Clin Oncol (ASCO Annual Meeting Proceedings) 2005;23:7138.

60. Santen RJ, Santner SJ, Pauley RJ, Tait L, Kaseta J, Demers LM, Hamilton C, Yue W, Wang JP. Estrogen production via the aromatase enzyme in breast carcinoma: which cell type is responsible? J Steroid Biochem Mol Biol 1997;61:267-71. [PubMed: 9365200]

61. Santner SJ, Pauley RJ, Tait L, Kaseta J, Santen RJ. Aromatase activity and expression in breast cancer and benign breast tissue stromal cells. J Clin Endocrinol Metab 1997;82:200-8. [PubMed: 8989259]

62. Cuzick J, Sasieni P, Howell A. Should aromatase inhibitors be used as initial adjuvant treatment or sequenced after tamoxifen? Br J Cancer 2006;94:460-4. [PubMed: 16434989]

63. Paget S. The distribution of secondary growths in cancer of the breast. Lancet 1889;1:571-3.

64. Clezardin P. Anti-tumour activity of zoledronic acid. Cancer Treat Rev 2005;31:1-8. [PubMed: 16225995]

65. Smith MR. Zoledronic acid to prevent skeletal complications in cancer: corroborating the evidence. Cancer Treat Rev 2005;31:19-25. [PubMed: 16229955]

66. Hortobagyi GN. Moving into the future: treatment of bone metastases and beyond. Cancer Treat Rev 2005;31:9-18. [PubMed: 16249057]

67. Sporn MB. Dichotomies in cancer research: some suggestions for a new synthesis. Nat Clin Pract Oncol 2006;3:364-73. [PubMed: 16826217]

\section{Abbreviations}

CSF Colony stimulating factor

NSAID Non-steroidal anti-inflammatory drug

PDGF Platelet derived growth factor

SNP Single nucleotide polymorphism

TGF Transforming growth factor

TNF Tumor Necrosis Factor

VEGF Vascular endothelial growth factor 
Table 1

Microenvironmental processes targeted by existing and developing treatments

\begin{tabular}{|l|l|}
\hline Microenvironmental target & Therapeutic agent \\
\hline Estrogen biosynthesis & Aromatase inhibitors (anastrozole, letrozole and exemesthane) \\
\hline Macrophage-Tumor interactions & Anti-CSF1 monoclonal antibody \\
\hline & Trabectedin \\
\hline Prostaglandin production & Cox2 inhibitors (e.g. Non-steroidal anti-inflammatory drugs) \\
\hline Metastatic microenvironment in bone & Osteoclast targeting agents (e.g. zoledronic acid, clodronate) \\
\hline Stromal-epithelial interaction & TGF-beta inhibitors (e.g. SB-431542, LY580276, Lerdelimumab) \\
\hline & TNF-alpha inhibitors (e.g. Etanercept, Infliximab) \\
\hline Angiogenesis & Anti-VEGF monoclonal antibody (Bevacizumab) \\
\hline & VEGF Receptor inhibitors (e.g. BAY-43-9006) \\
\hline & PDGF Receptor inhibitor (e.g. Gleevec) \\
\hline & $\begin{array}{l}\text { Pro-angiogenic integrins inhibitors (e.g. endostatin and other ECM } \\
\text { fragments) }\end{array}$ \\
\hline & Thalidomide (several possible mechanisms) \\
\hline
\end{tabular}

